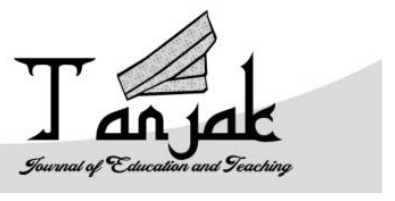

Tanjak: Journal of Education and Teaching

ISSN 2716-4098 (P) 2720-8966 (O)

Volume 1 Nomor 1, 2020

\title{
ANALISIS SOAL-SOAL UJI KOMPETENSI PADA BUKU TEKS MATEMATIKA SMA KELAS XI PEMINATAN IPASEMESTER 1 BERDASARKAN TINGKAT KOGNITIF TAKSONOMI BLOOM
}

\author{
Agus Suharman $^{1 *}$, Rezky Ramadhona ${ }^{2}$ \\ agussuharman8@gmail.com \\ 1,2 Universitas Maritim Raja Ali Haji, Tanjungpinang, Kepulauan Riau 29135, Indonesia
}

DOI: https://doi.org/10.35961/tanjak. v1i1.81

\begin{abstract}
Abstrak
Tujuan penelitian ini adalah menganalisis soal-soal uji kompetensi pada buku teks matematika SMA kelas XI Peminatan IPA berdasarkan tingkat kognitif taksonomi bloom. Penelitian ini menggunakan metode studi kasus dengan rancangan deskriptif. Subjek penelitian ini adalah soal-soal uji kompetensi buku teks matematika kelas XI Peminatan IPA semester 1 hasil revisi kurikulum 2013. Sebanyak135 soal dikaji dengan rincian 30 soal materi trigonometri, 55 soal materi persamaan lingkaran, dan 50 soal materi polinomial. Pada penelitian ini setiap soal akan dianalisis tingkat kognitifnya berdasarkan taksonomi bloom. Hasil penelitian ini adalah persentase soal untuk masing-masing tingkat kognitif adalah: C1 (0\%), C2 (11,11\%), C3 (19,26\%), C4 (51,11\%), C5 (18,52), dan C6 $(0 \%)$.
\end{abstract}

Kata kunci: Analisis Soal; Buku Teks Matematika; Taksonomi Bloom.

Tanjak: Jounal of Education and Teaching, Vol. 1, No. 1, 2020 


\begin{abstract}
Garamond, sp. 1.15)
The purpose of this study was to analyze the mathematics competency test questions math teks book grade XI specialization in IPA based on cognitive taxonomic bloom levels. This research uses a case study method with descriptive design. The subjects of this study were the mathematics competency test questions math teks book grade XI specialization in IPA in the 1st semester in the 2013 curriculum revision. A total of 135 questions were examined with details of 30 trigonometric material questions, 55 circular equation material questions, and 50 polynomial material questions. In this study each question will be analyzed its cognitive level based on bloom taxonomy. The results of this study are the percentage of questions for each cognitive level are: C1 (0\%), C2 (11.11\%), C3 (19.26\%), C4 (51.11\%), C5 (18.52), and C6 (0\%).
\end{abstract}

\title{
Keywords: Analysis Questions; Math Teks Book; Taxonomy Bloom.
}

\section{Pendahuluan}

(Buku teks adalah salah satu alat atau sumber pembelajaran yang penting. Dalam Peraturan Pemerintah Nomor 32 Tentang 2013 Tentang Perubahan Atas Peraturan Pemerintah Nomor 19 Tahun 2005 Tentang Standar Nasional Pendidikan pasal 1 ayat 23, disebutkan bahwa buku teks pelajaran adalah sumber pembelajaran utama untuk mencapai kompetensi dasar dan kompetensi inti. Meskipun bersifat konvesional, keberadaan buku teks sangat membantu pendidik dalam melakukan pembelajaran. Zulkardi (2002) menyatakan bahwa pada praktiknya contoh penyelesaian masalah yang dipresentasikan oleh guru, yang ditugaskan untuk dikerjakan siswa, dan yang dijadikan pekerjaan rumah oleh siswa berasal dari soal pada buku teks.

Fatimah (2017) mengatakan bahwa matematika sebagai dasar dari ilmu-ilmu lain merupakan salah satu mata pelajaran di sekolah yang dapat meningkatkan daya pikir peserta didik dengan kemampuan berpikir logis, analitis, kritis, dan kreatif. Hal ini sejalan dengan definisi matematika menurut Hudojo (2003) bahwa matematika merupakan suatu alat untuk mengembangkan cara berpikir, bersifat abstrak, penalarannya bersifat edukatif dan berkenaan dengan gaggasan terstruktur yang hubungan-hubungannya diatur secara logis. Oleh karena itu, matematika harus dipelajari secara terstruktur dan sistematis agar mudah dipahami oleh peserta didik. Buku teks matematika sebagai sumber pembelajaran harus mampu menyajikan informasi yang tidak hanya terstruktur dan sistematis tetapi juga mamp untuk menjadi tolak ukur pemahaman siswa terhadap materi berdasarkan tingkat kognitifnya. Sehingga matematika peserta didik mampu menerapkan apa yang mereka pelajari pada kehidupan sehari-hari.

Namun kenyataannya, masih banyak ditemukan buku teks yang digunakan sebagai sumber pembelajaran yang tidak memenuhi kriteria tersebut. Dalam penelitian Masduki dkk (2003) ditemukan bahwasannya masih rendahnya proporsi soal-soal dalam buku teks yang mendorong siswa untuk mampu menggunakan kemampuan penalaran mereka untuk menyelesaikan masalah matematika. Selaras dengan penelitian Masduki dkk, penelitian Rinawati \& Utami (2013) menemukan fakta bahwa soal-soal dalam buku teks matematika ternyata masih belum memfasilitasi siswa untuk mencapai kompetensi dasar. 
Pemerintah melalui Badan Standar Nasional Pendidikan (BSNP) melakukan kontrol terhadap buku teks dengan cara penilaian untuk memastikan buku teks tersebut memenuhi standar yang telah ditetapakan. Sebelum ditetapkan sebagai sumber pembelajaran buku teks dinilai terlebih dahulu oleh BSNP. Adapun yang menjadi kriteria penilaiannya, yaitu: kelayakan isi, bahasa, penyajian, dan kegrafikaan (BSNP, 2014). Sedangkan untuk buku teks matematika terdapat beberapa kriteria tambahan, yaitu: keakuratan fakta, konsep, prinsip, prosedur, contoh, dan soal (Kemendiknas, 2008).

Taksonomi merupakan cara pengkategorian. Taksonomi memudahkan pendidik untuk membuat klasifikasi materi apa saja yang harus dipelajari oleh anak didiknya. Benjamin S. Bloom pada tahun 1949 mengajukan idenya mengenai pembagian/ pengkategorian untuk mempermudah proses penyusunan bank soal sehingga mempunyai tujuan pembelajaran yang sama meski disusun oleh orang yang berbeda. Bloom mempublikasikan idenya tersebut yang dikenal dengan Taksonomi Bloom pada tahun 1956. Kemudian David R. Krathwohl bersama timnya mengajukan usul revisi terhadap Taksonomi Bloom tersebut.

Anderson, L.W \& Krathwohl, D.R (Krathwol, 2002) merevisi taksonomi bloom yang lama, sehingga membagi tingkatannya antara lain mengingat (C1), memahami (C2), mengaplikasikan (C3), menganalisis (C4), mengevaluasi (C5) dan mencipta (C6). Menurut pendapat Krathwol bahwa taksonomi yang direvisi menekankan pada struktur dua dimensi yang meliputi pengetahuan dan proses berpikir kognitif. Keenam kategori taksonomi yang telah direvisi disusun dalam suatu tingkatan yang terurut yaitu dari level terendah (mengingat) hingga level tertinggi (mencipta).

Masih mengutip sumber yang ditulis oleh Krathwol, penjelasan subkategori taksonomi bloom revisi yaitu remember/mengingat (C1), kategori ini mencakup dua macam proses kognitif yaitu mengenali (recognizing) dan mengingat kembali (recalling). Kemudian understanding/memahami (C2), tingkatan ini menekankan bahwa siswa harus memilih fakta-fakta dan konsep yang cocok untuk menjawab pertanyaan. Jawaban siswa tidak sekedar mengingat kembali informasi, namun harus menunjukkan pengertian terhadap materi yang diketahuinya. Kategori apply/mengaplikasikan (C3) yang mencakup dua macam proses kognitif yaitu menjalankan (executing) dan mengimplementasikan (implementing). Lalu kategori analyze/me-nganalisis (C4) yang mengarahkan pada kemampuan seseorang untuk merinci/menguraikan suatu bahan/keadaan menurut bagian-bagian yang lebih kecil dan mampu memahami hubungan diantara bagian-bagian yang satu dengan yang lainnya. Kategori evaluate/mengevaluasi (C5) yang meliputi dua macam proses kognitif yaitu memeriksa (checking) dan mengkritik (critiquing). Tingkatan tertinggi yaitu create/mencipta (C6) melibatkan tiga macam proses kognitif yang tergolong dalam kategori ini yaitu membuat (generating), merencanakan (planning), dan memproduksi (producing).

\section{Metode Penelitian}

Metode yang digunakan dalam penelitian ini adalah metode penelitian deskriptif. Menurut Punaji (2010), penelitian deskriptif merupakan penelitian yang tujuannya untuk menjelaskan atau mendeskripsikan suatu peristiwa, keadaan, objek apakah orang, atau segala sesuatu yang variabelvariabelnya bisa dijelaskan baik menggunakan angka-angka maupun kata-kata. 
Objek penelitian ini adalah soal-soal uji kompetensi pada buku teks matematika kelas XI Peminatan IPA semester 1 hasil revisi kurikulum 2013 dengan keselurahan total soal yang dikaji sebanyak 135 soal. Dengan rincian materi berdasarkan kompetensi dasar yaitu: aturan jumlah dan selisih sinus dan cosinus, persamaan dan pertidaksamaan trigonometri, lingkaran dan persamaan lingkaran, dan faktorisasi polinomial.

\section{Hasil dan Pembahasan}

Buku teks matematika kelas XI Peminatan IPA hasil revisi kurikulum 2013 yang dikeluarkan oleh Kementerian Pendidikan dan Kebudayaan merupakan hasil revisi dari buku sebelumnya yang berpatokan pada kurikulum 2013. Pada buku teks ini mencakup 2 semester sekaligus, namun pada penelitian ini hanya mengkaji soal-soal yang terdapat pada semester 1. Tabel berikut ini akan menyajikan hasil pengkajian soal-soal berdasarkan tingkat kognitif taksonomi bloom.

Tabel 1. Sebaran soal berdasarkan tingkat kognitif taksonomi bloom

\begin{tabular}{|c|c|c|c|c|c|c|}
\hline $\begin{array}{l}\text { Bab/Tingkatan } \\
\text { Kognitif }\end{array}$ & $\mathrm{C} 1$ & $\mathrm{C} 2$ & $\mathrm{C} 3$ & $\mathrm{C} 4$ & C5 & C6 \\
\hline $\begin{array}{l}\text { Bab 1: } \\
\text { Trigonometri }\end{array}$ & - & $\begin{array}{l}7,8,27, \\
28\end{array}$ & $\begin{array}{l}1,2,3,4,5,9 \\
10,26\end{array}$ & $6,11-25,29,30$ & - & - \\
\hline $\begin{array}{l}\text { Bab 2: } \\
\text { Persamaan } \\
\text { Lingkaran }\end{array}$ & 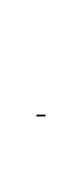 & $\begin{array}{l}1-4,46, \\
47\end{array}$ & $5,6,9,10,49$ & $\begin{array}{l}7,8,11-22,27-31 \\
48,50-52\end{array}$ & $\begin{array}{l}23-26,32 \\
-45,53- \\
55\end{array}$ & - \\
\hline $\begin{array}{l}\text { Bab 3: } \\
\text { Polinomial }\end{array}$ & 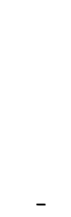 & $31-35$ & $\begin{array}{l}3,7,11,12,14 \\
-17,28,29, \\
40,47,48\end{array}$ & $\begin{array}{l}1,2,4-6,8-10,13, \\
18-27,30,36-39, \\
41,46,49,50\end{array}$ & $42-45$ & - \\
\hline Total & 0 & 15 & 26 & 69 & 25 & 0 \\
\hline Persentase total & $0 \%$ & $11,11 \%$ & $19,26 \%$ & $51,11 \%$ & $18,52 \%$ & $0 \%$ \\
\hline
\end{tabular}


Pada bab I, tentang trigonometri soal hanya berkisaran pada tingkat C2 (4 soal), C3 (8 soal), dan C4 (18 soal). Sedangkan untuk tingkat C1, C5, dan C6 tidak ada soal yang mewakili sama sekali. Pada bab II dan bab III soal tingkat C5 mulai disajikan namun untuk soal tingkat C1 dan C4 belum terdapat soal yang mewakili. Jika dibandingkan ketiga bab tersebut maka akan terlihat bahwa soal-soal uji kompetensi mendominasi di sekitar level C3 (mengaplikasikan), C4 (menganalisis), dan C5 (mengevaluasi).

Secara keselurahan dapat dilihat bahwasannya soal tingkat C4 sangat mendominasi, melebihi setengah dari total soal yang dikaji, yaitu sebanyak 69 soal atau 51,11\%. Kemudian disusul soal tingkat C3 dan C5 yang hanya selisih satu soal saja, masing-masing dengan persentase 19,26\% dan 18,52\%. Soal tingkat C2 dengan jumlah total paling sedikit dibandingkan 3 tingkatan lainnyaa, yaitu hanya 15 soal atau 11,11\%.

\section{Kesimpulan}

Tingkat kognitif memang mempunyai hubungan yang erat dengan bobot soal. Semakin tinggi tingkat kognitifnya maka semakin tinggi pula bobot soal tersebut. Namun bukan bearti soal dengan tingkat kognitif yang rendah dapat dilewati begitu saja. Dari hasil terlihat bahwa tidak ada satupun soal yang bertingkat C1 (mengingat). Padahal mengingat merupakan fondasi awal yang dibutuhkan oleh peserta didik untuk bisa melangkah ke tingkatan selanjutnya.

Selain itu, tidak ada satu soalpun yang menyentuh tingkat kognitip C6 (mencipta). Hal ini juga menjadi catatan penting bagi pendidik karena sejatinya tujuan pembelajaran matematika tidak hanya untuk menguasai materi saja tetapi peserta didik diharapkan mampu untuk mengaplikasikan apa yang dipelajari pada kehidupan sehari-hari. Untuk itu diperluykan suatu tingkatan soal yang dapat membiasakan peserta didik untuk berpikir suatu alternatif untuk menyelesaikan suatu permasalahan.

Terakhir, Berdasarkan kesimpulan yang diperoleh, saran yang dapat diberikan adalah bagi pendidik perlu cermat dalam memberikan soal-soal latihan yang merujuk pada buku teks. Hal ini berkaitan dengan hasil penelitian yang telah dilakukan menemukan fakta bahwa soal- soal latihan yang tersedia pada buku teks ternyata masih belum memfasilitasi siswa untuk mencapai kompetensi dasar sesuai dengan kurikulum yang berlaku.

\section{Referensi}

BSNP. 2014. Instrumen Penilaian Buku Teks Pelajaran. Jakarta: Badan Stadar Nasional Pendidikan.

Depdikbud. 2013. Peraturan Pemerintah Nomor 32 Tahun 2013 Tentang Standar Nasional Pendidikan. Jakarta: Depdikbud.

Hudojo, H. 2003. Pengembangan Kurikulum dan Pembelajaran Matematika. Malang: Universitas Negeri Malang.

Kemendiknas. 2008. Peraturan Menteri Pendidikan Nasioanl Nomor 34 Tahun 2008. Jakarta: Kementerian Pendidikan Nasional.

Krathwol, D. R. 2002. A Revision of Bloom’s Taxonomy: An Overview. 
Masduki, dkk. 2013. Level Kognitif Soal-Soal pada Buku Teks Matematika SMP Kelas VII. Yogyakarta: Universitas Negeri Yogyakarta.

Rinawati \& Utami, T. H. 2013. Analisis Kesesuaian Soal-Soal Latihan pada Buku Teks Mateamtika SMA Kelas X dengan Kompetensi Dasar Berdasarkan Ranah Kognitif Taksonomi Bloom. Dalam jurnal 425 KNPM V. Himpunan Matematika Indonesia.

Risminawati, F. P. 2017. Analisis Materi, Penyajian Bahasa Buku Teks Matematika SMP Kelas VIII di Kabupaten Sragen Tahun Ajaran 2015/2016. Surakarta: Universitas Muhammadiyah Surakarta.

Setyosari, P. 2010. Metode Penelitian dan Pengembangan. Jakarta: Kencana.

Zulkardi. 2002. Develoving a Learning Environment on RME for Indonesian Student Teachers. Enschede: University of Twente. 